\title{
AGRICULTURAL COOPERATIVE FIRMS: BUDGETARY ADJUSTMENTS AND ANALYSIS OF CREDIT ACCESS APPLYING SCORING SYSTEMS
}

\author{
Giuseppe Bonazzi and Mattia Iotti \\ Department of Food Science, University of Parma, Parma, Italy
}

Received 2014-02-22; Revised 2014-03-16; Accepted 2014-05-05

\begin{abstract}
Cooperatives are one of the most important types of companies in the agricultural sector. Cooperatives allow overcoming the limitations of the fragmentation of agricultural property, increasing the level of production of small-sized farms and selling the product so that it reaches a sufficient critical mass. Moreover, cooperatives are often characterized by undercapitalization and even difficult credit access because banks conduct their analysis applying rating systems that do not take into account the typicality of the cooperative budget. To assess this topic, in this article, an analysis has been conducted on a sample of 100 cooperatives, making adjustments to the annual budget in order to consider the typicality of their annual accounts. The results of the analysis show that suggested adjustments allow a more correct expression of the economic results and capital adequacy of the cooperative and that the results, expressed in terms of scoring, are higher than that achieved by a traditional analysis. This methodology could improve the credit access capacity for agricultural cooperatives and then reduce financial constraints, particularly in developing countries.
\end{abstract}

Keywords: Agricultural Cooperative Firms, EM-Score, DuPont Approach, Credit Access, Scoring System

\section{INTRODUCTION}

Cooperative enterprises are of great importance in the agricultural sector worldwide, as expressed in several studies. Food and Agriculture Organization of the United Nations FAO shows that for the World Food Day 2012, about 1 billion people are members of cooperatives, cooperatives create 100 million jobs in the world and $45 \%$ of the world's agricultural production is owed to the activity of cooperatives. In developing countries, cooperation is of great importance because it allows the limitations imposed by the difficulty of capital accumulation to be overcome (Cotteril, 1987; Fulton et al., 1995; Chaddad et al., 2005; Mishra et al., 2009). In fact, in a cooperative, individual members can contribute, even with small amounts of money, to finance the activities in terms of loans or equity, overcoming the problem of the accumulation of capital owned by a few entrepreneurs as in a limited company. With this, even if there is a Corresponding Author: Giuseppe Bonazzi, Department of Food Science, University of Parma, Parma, Italy

scarcity of capital, individual farmers can join a cooperative and start a business of which they are members. The cooperative can thus overcome the problem of separation of ownership and control (Hendriske and Veerman, 2001). In fact, in a cooperative, all those who work or who bring their products are members. Only in large cooperatives is there a separation between ownership and control and the cooperative takes the form of a managerial enterprise (Hendriske and Bijman, 2002; Cook, 1995). Cooperative enterprises are essentially of two types (LeVay, 1983). There are cooperatives of workers and cooperatives of conferment. In worker cooperatives, the members conduct their work activities in the cooperative and receive a salary that is determined when the profit of the cooperative is considered; very often, a minimum wage is paid during the year and a premium is then paid at the end of the year, after accounting the profit of the cooperative. In this, cooperative members directly work

AJAS 
in the farm as laborers, pastors, operators of dairies, or porters and each activity is based on professional capacity. In a conferment cooperative, the mechanism for the remuneration of cooperative members is the same, even if the members of the cooperative are not workers but farmers. The individual members, each having a farm that produces agricultural products, confers these products in the cooperative to be processed. The agricultural cooperative transforms agricultural products given by the members and shares the profits. The remuneration of agricultural products conferred by the cooperative members may be higher than the market price of agricultural products or may be lower, depending on the efficiency of the management of the cooperative. If the value of the remuneration is higher than the market price at which the member could sell the product, the member has an advantage to confer the agricultural production to the cooperative. Conferment cooperatives have been operating for many years in the milk processing sector, particularly in the countries of the Mediterranean Basin and in the United States and in sectors processing fruits and vegetables to produce canned vegetables and fruit juices in different states of Africa and South America (Rathbone, 1995). Cooperatives are agricultural enterprises of great importance, particularly in social situations where there is no large concentrations of capital stock that allow the development of a modern food processing industry (Rogers and Marion, 1990; Cook and Chaddad, 2004). In addition, because of the presence of farmers as members, cooperatives promote human development in the rural areas (Sexton, 1990). In fact, agricultural cooperation produces profit from production and transformation and this profit remains in the local areas and is distributed to farmers (Bonazzi et al., 2009) even considering their impact on related agricultural activities (Theodoropoulou et al., 2008) On the contrary, the presence of large enterprises that are not based locally has resulted in earning streams leaving the territory in which processing takes place, without activating the multiplication of income. However, cooperatives, despite being so important for the social and economic development of rural areas, are disadvantaged; cooperatives are often characterized by undercapitalization and have difficult access to credit, as shown in several studies (Cook, 1995; Fulton et al., 1995; Tirole and Rey, 2001; Ellinger, 2009). In particular, in emerging countries is important the analysis of access to credit. In fact, agricultural enterprises have often problems of underfunding, particularly when operating as a cooperative
(Limsombunchai et al., 2005) In addition, in the event of liquidation of the cooperative, different national regulations (such as the Italian and the Spanish law) do not allow the division of equity capital between the cooperative members. With this, the members become uninterested to confer equity capital in cooperatives because they cannot have it back in the liquidation phase. The low level of equity capital by shareholders-that is, the undercapitalization of cooperatives-causes difficulties in the access to credit for these companies, even if cooperatives are not always really undercapitalized; in fact, members often do not confer equity capital but shareholder loans. In addition, the cooperative's real profit is higher than it appears in the annual account; in fact, in the income statement, we can often find an overpayment of the purchase cost of agricultural raw materials given by members. This overcompensation reduces the profit of the cooperative and allows the distribution of the share of profits with direct remuneration of the members, paying a price higher than the market price of the agricultural raw materials conferred (Albaek and Schultz, 1998). To analyze this topic, the most important database is the cooperative's annual account (budget). The cooperative has a budget that is the same with that of a corporation and is composed of an income statement, a balance sheet and a financial statement. The income statement quantifies the profit of the cooperative, the balance sheet quantifies the investment and capital sources, whereas the cash flow statement quantifies the revenues and expenditures of the company's money. Cooperatives have a typicality of budget that makes this type of enterprise hardly analyzed applying traditional financial ratios developed in the DuPont ratios approach. In fact, the traditional financial ratios have been designed for corporations, where the Return on Equity (ROE) is based on the distribution of profits and there is separation between ownership and control of the company. Instead, cooperative enterprises have elements of their budget that make the management of cooperatives different from that of corporations. First, the remuneration of the work or goods is conducted not only via profits but also with remuneration of the members' services at a price higher than what they would receive from directly selling their goods on the market. The differential remuneration that exists between the price paid by the cooperative and the market price represents a share of profits to the shareholders. This element of typicality (typicality 1.a) of the cooperative management is not made explicit in corporate balance sheets and therefore is not considered 
by banks in the rating systems. Frequently, members give loans (so-called social lending) and these funds are not part of the equity capital but are recorded in the balance sheet as amounts due to shareholders (typicality 2.a). Generally, these loans generate interest expense charged to the company (typicality 2.b). The funding of the members are capital contributions and the interest expense charged to the company shall be treated as a distribution of profits in return on capital provided by shareholders. These two typicalities (2.a and 2.b) are not spelled out in the company's annual account and therefore are not considered by banks in the rating system. The real budget of the cooperative, therefore, needs a reclassification, taking into account typicalities 1.a, 2.a and 2.b. To achieve this goal, it is necessary to dispose some budgetary adjustments. The costs of purchase of agricultural commodities in the income statement should be adjusted to take into account the over-or underremuneration that the raw materials, conferred by members, have in the cooperative income statement. The overremuneration shall be considered as profit, while underremuneration shall be considered as loss. In case of overremuneration, it is necessary to reclassify the income statement, reducing the purchasing cost of raw materials in the annual account for an amount equal to overremuneration at the market prices and to increase profit for the same amount (assuming that there is no difference in taxation). This is a situation in which it is convenient for members to confer agricultural products in the cooperative compared with selling these in the market. These adjustments are necessary to correctly express typicality 1 .a of the budget of the cooperative. In addition, it is necessary to adjust the balance sheet of the cooperative considering the loans by members as values of equity capital, thereby reducing shareholders' loans and increasing the equity capital. It is also necessary to exclude financial costs of remuneration of shareholders' loans, considering these values as part of profit (always assuming that there is no difference in taxation). These adjustments are necessary to correctly express typicalities 2.a and 2.b. We can then consider that cooperatives are often characterized by undercapitalization and difficult credit access. In fact, banks conduct their analysis for the access to credit applying rating systems that do not take into account the typicality of the cooperative budget. When these adjustments (1.a, 2.a and 2.b) are taken into account, the balance sheet of the cooperative is able to correctly represent the economic and the financial position of the cooperative firm and this is the annual account that banks should correctly analyze for the granting of credit to the cooperative. In this article, a methodology that takes into account the cited adjustments of the budget is therefore proposed, recalculating the cooperative data in order to highlight the real operating results. We define these statements as a reclassified cooperative annual account. We then apply to the annual account of cooperatives, reclassified and not reclassified, the financial ratios calculated according to the traditional DuPont approach to verify if there are significant differences between annual account ratios calculated using these two different approaches. Furthermore, an index used by banks to assess the credit risk (Altman EM-Score) is also calculated; this index, starting from the data of the annual account, makes it possible to quantify the credit risk related to a single company. Because this index is calculated on the basis of budgetary data, there may be an over- or underestimation of the index, as the annual account of the cooperative does not take into account the reclassifications that we suggest. In this article, we then calculate the EM-Score considering the annual account in the reclassified and the nonreclassified form. The EM-Score calculated on the nonreclassified annual account is compared with the cooperativeadjusted EM-Score that is calculated on the reclassified annual account. In this way, it is possible to examine whether there are significant differences between the values of the two indices and between the individual parameters of them. If there are significant differences between the two indices, it is confirmed that access to credit for cooperatives is affected by the typicality of the annual account of these companies. Therefore, it is necessary to reclassify the budget of the cooperative, as suggested in the methodological part of this article, to properly express the economic and financial results of the management. In this way, cooperatives can be properly assessed by banks when applying for funding and without this analysis, the cooperative form negatively affects credit access.

\section{MATERIAL AND METHODS}

In this article, the analysis is carried out on a sample of 100 cooperatives, applying adjustments to the annual account in order to make the data of the cooperative and the data of limited liability companies comparable with each other and to correctly calculate ratios and scoring indices; to analyze the typicality of cooperative's data, we suggest adjustments and 
subject results obtained from the statistical test. To achieve the goal, it is necessary to do the following:

- Analyze the predictive models of credit risk and identify the model that is applied in the research

- Analyze the annual account of the cooperative to determine the adjustments necessary to prepare the cooperative's reclassified annual account

- Analyze models for the analysis of financial ratios, considering the DuPont approach that is used in research and applying it to cooperative data

\subsection{The Credit Risk Models}

The accounting information contained in the annual account have been analyzed by many researchers for various reasons; some studies have focused on the use of financial ratios for decisions by managers, such as (AlRazeen and Karbhari, 2004; Al-Ajmi, 2008; Alrafadi and Md-Yusuf, 2011). The financial ratios are also used to quantify the value of the firm (Fama and French, 1996; 1998) or the analysis of the turnaround (Pearce, 2007). Accounting ratios are very often used for the assessment of credit risk. These analyses lead to the construction of models to predict insolvency; bankruptcy prediction models are applied to analyze the level of financial distress experienced by firms or to quantify the risk of future financial distress. Researchers have applied several models for different methodologies such as Multiple Discriminant Analysis (MDA), logit and probit regression models and neural networks. The first major works on the subject of credit risk are developed during the '60s. The first study (Beaver, 1966) applied univariate analysis, whereas the seminal study of Altman (1968) applied an MDA. Altman's analysis considers five ratios for the calculation of a single score (Altman Z-Score) that aims to define the risk of default of the company. In recent years, several researchers have applied new approaches to predict corporate failure, as neutral network (Nguyen, 2005) and Risk Box Approach by Genetic Programming Method (Bahiraie et al., 2009). In the study, Altman considers 22 potential explanatory variables to quantify the final discriminant function that is expressed as follows:

$$
\begin{aligned}
& \mathrm{Z}(\mathrm{Z} \text {-Score })=\alpha_{1} \mathrm{X}_{1}+\alpha_{2} \mathrm{X}_{2}+\alpha_{3} \mathrm{X}_{3}+\alpha_{4} \mathrm{X}_{4}+\alpha_{5} \mathrm{X}_{5} \\
& =1.2 \mathrm{X}_{1}+1.4 \mathrm{X}_{2}+3.3 \mathrm{X}_{3}+0.6 \mathrm{X}_{4}+0.999 \mathrm{X}_{5}
\end{aligned}
$$

In Equation 1, $\mathrm{Z}$ is the Altman Z-Score, $\mathrm{X}_{1}$ is (NWC $+\mathrm{L}^{\mathrm{f}}$ )/TA, $\mathrm{X}_{2}$ is $\mathrm{E}^{\mathrm{r}} / \mathrm{TA}, \mathrm{X}_{3}$ is EBIT/TA, $\mathrm{X}_{4}$ is $\mathrm{E}^{\mathrm{sc}} / \mathrm{TA}$ and $\mathrm{X}_{5}$ is VP/TA. Altman recommended a cutoff point of 2.675; firms with a score value of less than 2.675 are predicted to be bankrupt and firms with values higher than 2.675 are predicted to be nonbankrupt. The Z-Score has undergone several adaptations by (Altman, 1993; Altman et al., 1998; Altman and Ong, 2002) to apply it to unlisted companies. Altman suggests the Z" (EMScore) model, in which $\mathrm{X}_{5}$ is not considered to be influenced by the firm's sector. The Altman EM-Score formulation is as follows Equation 2:

$$
\begin{aligned}
& \text { Z"(EM-Score })=\alpha_{1} X_{1}+\alpha_{2} X_{2}+\alpha_{3} X_{3}+\alpha_{4} X_{4}+\alpha_{5} \\
& =6.56 X_{1}+3.26 X_{2}+6.72 X_{3}+1.04 X_{4}+3.25
\end{aligned}
$$

where, $X_{1}$ is $\left(\mathrm{NWC}+\mathrm{L}^{\mathrm{f}}\right) / \mathrm{TA}, \mathrm{X}_{2}$ is $\mathrm{E}^{\mathrm{r}} / \mathrm{TA}, \mathrm{X}_{3}$ is EBIT/TA and $\mathrm{X}_{4}$ is $\mathrm{E}^{\mathrm{sc}} / \mathrm{TA}$; the analysis of EM-Score and its application in the assessments used equivalence scale values between the EM-Score and the quality of the debt; EM-Score values above 3.75 express an investment grade rating (rating classes B-and above), whereas values less than or equal to 3.75 express a noninvestment grade rating (rating classes $\mathrm{CCC}+$ and lower); EM-Score values less than or equal to 1.75 indicate a high-risk company default (class D equivalence scale). The EM-Score is used mainly in evaluating the credit capacity of Smalland Medium-Sized Enterprises (SMES) operating in the manufacturing sector; for this reason, the EM-Score is applied to firms in the sample to assess financial risk and the firm's ability to obtain credit by banks.

\subsection{The Cooperatives' Reclassified Annual Account}

The annual account of the firm is divided into the income statement and the balance sheet. The income statement quantifies the profit, whereas the balance sheet quantifies investments and sources of capital. The income statement is expressed as follows:

$$
\begin{aligned}
& \mathrm{VP}-(\mathrm{R}+\mathrm{S}+\mathrm{L}+\mathrm{O})= \\
& \mathrm{EBITDA} ; \mathrm{EBITDA}-(\mathrm{D}+\mathrm{A})=\mathrm{EBIT} \\
& \mathrm{EBIT} \pm \mathrm{SF} \pm \mathrm{SX}=\Pi^{\mathrm{aT}} ; \Pi^{\mathrm{aT}}-\mathrm{T}=\Pi^{\mathrm{pT}^{\mathrm{T}}}
\end{aligned}
$$

In Equation 3, VP is the value of production, $\mathrm{R}$ is the purchase cost of raw materials, $\mathrm{L}$ is labor costs, $\mathrm{O}$ is other operating costs, EBITDA is earnings before interest and tax, D is depreciation, $\mathrm{A}$ is amortization, EBIT is earnings before interest and tax, SF is balance of financial revenues and costs, SX is balance of extraordinary revenues and costs, $\Pi^{\mathrm{aT}}$ is profit before taxes, $\mathrm{T}$ is income taxes and $\Pi^{\mathrm{pT}^{\mathrm{T}}}$ is profit after tax. The balance sheet is expressed as follows: 
$\mathrm{FA}+\mathrm{WC}^{\mathrm{a}}+\mathrm{L}^{\mathrm{f}}=\mathrm{E}^{\mathrm{sc}}+\mathrm{E}^{\mathrm{r}}+\Pi^{\mathrm{pr}}+\mathrm{D}^{\mathrm{f}}+\mathrm{D}^{\mathrm{s}}+\mathrm{WC}^{\mathrm{l}}$

In Equation 4, FA is fixed assets, $\mathrm{WC}^{\mathrm{a}}$ is working capital assets, $\mathrm{L}^{\mathrm{f}}$ is financial liquidity and $\mathrm{FA}+\mathrm{WC}^{\mathrm{A}}+$ $\mathrm{L}^{\mathrm{f}}$ is Total Assets (TA). $\mathrm{E}^{\text {sc }}$ is equity share capital, $\mathrm{E}^{\mathrm{r}}$ is equity reserves, $\Pi^{\mathrm{pT}}$ is profit after taxes; $E^{\mathrm{sc}}+\mathrm{E}^{\mathrm{r}}+\Pi^{\mathrm{pT}}$ is total equity $\left(\mathrm{E}^{\mathrm{T}}\right)$. $\mathrm{D}^{\mathrm{f}}$ is financial debt, $\mathrm{D}^{\mathrm{s}}$ is debt to shareholders, $\mathrm{WC}^{\mathrm{l}}$ is working capital liabilities. $D^{f}+D^{s}+W C^{l}$ is total debt $\left(D^{T}\right)$. WC $-W C^{l}$ is Net Working Capital $(\mathrm{NWC}) \cdot \mathrm{E}^{\mathrm{T}}+\mathrm{D}^{\mathrm{T}}$ is TS and TS $=\mathrm{TA}$. The data in Equation 3 and 4 comprise the annual account, not reclassified budget. In this article, a reclassified budget is applied instead, in which three reclassifications are applied, to consider the typical characteristic of the cooperative annual account data. The first of these relates to the reclassification of the purchase value of raw materials at market prices. In fact, the contribution of cooperatives' utilization of raw materials conferred by the shareholders is defined as a payment at a price that may be higher than the market price. In this way, members of the cooperative could gain an advantage over the sale on the market of the agricultural raw material sold to the cooperative. We can express this as follows:

$$
\mathrm{R}=\mathrm{r}_{1}^{\mathrm{coop}} \mathrm{q}_{1}+\ldots+\mathrm{r}_{\mathrm{n}}^{\mathrm{coop}} \mathrm{q}_{\mathrm{n}}=\sum_{\mathrm{i}=1}^{\mathrm{n}} \mathrm{r}_{\mathrm{i}}^{\mathrm{coop}} \mathrm{q}_{\mathrm{i}}
$$

In Equation 5, $\mathrm{n}$ is the number of raw materials purchased by the cooperative and $r^{\text {coop }}$ is the purchase price paid by the cooperative for each raw material (this price may be lower or higher than the market price). The purchase price at market prices of the $n$ raw materials purchased by the cooperative is expressed as follows:

$$
\mathrm{R}^{\mathrm{mkt}}=\mathrm{r}_{1}^{\mathrm{mkt}} \mathrm{q}_{1}+\ldots+\mathrm{r}_{\mathrm{n}}^{\mathrm{mkt}} \mathrm{q}_{\mathrm{n}}=\sum_{\mathrm{i}=1}^{\mathrm{n}} \mathrm{r}_{\mathrm{i}}^{\mathrm{mkt}} \mathrm{q}_{\mathrm{i}}
$$

In Equation $6, \mathrm{R}^{\mathrm{mkt}}$ expresses the cost of purchasing raw materials valued at market price and $\mathrm{r}^{\mathrm{mkt}}$ is the market price for each raw material. We consider the hypothesis that the agricultural raw materials conferred by the cooperative members may be paid at a price different from the market price, whereas other goods purchased on the market, not from cooperative members, by definition, are paid by the cooperative on the basis of the market price. The members have an advantage from the cooperative if the price paid for their agricultural products is higher than the market price-that is, the price at which shareholders may sell their agricultural products on the market. The formula is as follows: $\mathrm{R}^{\mathrm{coop}}-\mathrm{R}^{\mathrm{mkt}}=\mathrm{R}^{\Pi}$, where $\mathrm{R}^{\Pi}$ is the profit for the members of the cooperative that is paid in terms of a price higher than the market price for agricultural raw materials conferred by members. If $\mathrm{R}^{\Pi}>0$, members would have an advantage to the transfer of the agricultural raw materials of the cooperative, whereas if $\mathrm{R}^{\Pi}<0$, members would have no benefit because they get a return on the raw materials supplied to the cooperative less than the market price. The first correction (1.a) we suggest is then as follows Equation 7:

$$
\begin{aligned}
& \mathrm{VP}-\left(\mathrm{R}^{\mathrm{mkt}}+\mathrm{S}+\mathrm{L}+\mathrm{O}\right)= \\
& \operatorname{EBITDA} ; \mathrm{EBITDA}-(\mathrm{D}+\mathrm{A})=\mathrm{EBIT} \\
& \mathrm{EBIT} \pm \mathrm{SF} \pm \mathrm{SX}=\Pi^{\mathrm{aT}} ; \Pi^{\mathrm{aT}}-\mathrm{T}=\Pi^{\mathrm{pT}}+\mathrm{R}^{\Pi}
\end{aligned}
$$

The second correction ( $2 \mathrm{a})$ is related to the financing by the members of the cooperative in terms of loans; these loans are classified as debt payables to members of the cooperative $\left(\mathrm{D}^{\mathrm{s}}\right)$. In the reclassified annual account that we suggest, $\mathrm{D}^{\mathrm{s}}$ are considered as part of the equity and are expressed as $\mathrm{E}^{\mathrm{s}}$. The third adjustment (2.b) is related to financial charges on loans of members $\left(D^{s}\right)$. In fact, $\mathrm{D}^{\mathrm{s}}$ can determine borrowing costs that are paid by the company; these borrowing costs are negative items of profit and are considered in the income statement. We can express this as follows Equation 8:

$$
\mathrm{SF}=\mathrm{Ir}+\mathrm{Ic}^{\mathrm{Df}}+\mathrm{Ic}^{\mathrm{Ds}}
$$

Ir is interest revenue, $\mathrm{Ic}^{\mathrm{Df}}$ is interest charge on financial debt and $\mathrm{Ic}^{\mathrm{Ds}}$ is interest charge on shareholders debt. Borrowing costs should be considered as part of the profit; therefore, we propose the following formulation of the SF reclassified, considering $\mathrm{SF}^{\text {coop }}$, which is applied in this article Equation 9:

$\mathrm{SF}^{\text {coop }}=\mathrm{Ir}+\mathrm{Ic}^{\mathrm{Df}}+$

Given the proposed corrections (1.a, 2.a and 2.b), we can express the reclassified income statement of the cooperative, which is used in this article, as follows:

$$
\begin{aligned}
& \mathrm{VP}-\left(\mathrm{R}^{\mathrm{mkt}}+\mathrm{S}+\mathrm{L}+\mathrm{O}\right)=\mathrm{EBITDA} \\
& \mathrm{EBITDA}-(\mathrm{D}+\mathrm{A})=\mathrm{EBIT} \\
& \mathrm{EBIT} \pm \mathrm{SF}^{\mathrm{coop}} \pm \mathrm{SX}=\Pi^{\mathrm{aT}} ; \Pi^{\mathrm{aTcoop}}- \\
& \mathrm{T}=\Pi^{\mathrm{pT}}+\mathrm{R}^{\Pi}+\mathrm{Ic}^{\mathrm{Ds}} \quad \Pi^{\mathrm{pT}}+\mathrm{R}^{\text {coop }}+\mathrm{Ic}=\Pi^{\mathrm{pTcoop}}
\end{aligned}
$$

In Equation 10, $\Pi^{\text {aTcoop }}$ is cooperative reclassified pre-tax profit and $\Pi^{\text {pTcop }}$ is cooperative reclassified posttax profit. $\Pi^{\mathrm{pTcoop}}$ expresses the real profit for the cooperative's members. Equation 10 expresses the profit 
generated by the cooperative for the members with greater precision than Equation 3 does. If $\Pi^{\mathrm{pTcoop}}>\Pi^{\mathrm{pT}}$, cooperative members would have an advantage, but if $\Pi^{\mathrm{pTcoop}}<\Pi^{\mathrm{pT}}$, members would have a disadvantage with the cooperative and may have greater profit from directly selling their agricultural products on the market. In our hypotheses, we do not consider commercial costs and transaction costs caused by a direct sale on the market of agricultural commodities by the shareholders. The reclassified balance sheet of the cooperative is then expressed as follows:

$$
\mathrm{FA}+\mathrm{WC}^{\mathrm{a}}+\mathrm{L}^{\mathrm{f}}=\mathrm{E}^{\mathrm{sc}}+\mathrm{E}^{\mathrm{r}}+\Pi^{\mathrm{pTcoop}}+\mathrm{E}^{\mathrm{s}}+\mathrm{D}^{\mathrm{f}}+\mathrm{WC}^{\mathrm{l}}
$$

Equations 10 and 11 show the reclassified cooperative annual account that is considered in this article and on which the financial ratios are calculated according to the DuPont system and the scoring approach of the Altman EM-Score.

\subsection{Ratio Analysis According to the DuPont Approach}

The financial ratios are useful to quantify the return on investment, the liquidity level and the patrimonial strength of the company (Nissim and Penman, 2001). In order to analyze the viability of the approach, the DuPont system is often used, which is a common and useful way to assess and understand the drivers of profitability (Moss et al., 2009; Little et al., 2009), even for agrifood companies (Bonazzi et al., 2012). Blumenthal (1998) shows that the DuPont approach is useful in explaining how managerial decisions affect financial performance. Firer (1999) considers the DuPont model as a planning tool useful in analyzing and understanding the factors that affect the ROE of the firm, applying accounting relationships. Other researchers (Ross et al., 1999) further identify three key factors expressed by the DuPont approach: (1) Operating efficiency (quantified by profit margin), (2) asset use efficiency (quantified by asset turnover) and (3) financial leverage (quantified by equity multiplier). Most researchers (Tianwei and Ellinger, 2006; Ashbaugh-Skaife et al., 2006) consider ROE as the firm's most important ratio, useful to express the ROE capital. The expression of ratios allows us to decompose ROE with the additive formula. If we consider a situation in which there are no extraordinary incomes and costs and the sources of capital are only equity $\left(\mathrm{E}^{\mathrm{T}}\right)$ and debt $\left(\mathrm{D}^{\mathrm{T}}\right)$, we can decompose ROE as follows Equation 12:

$$
\begin{aligned}
& \text { Roe }=\left[\frac{\text { EBIT }}{\mathrm{TA}}+\left(\frac{\mathrm{EBIT}}{\mathrm{TA}}-\frac{\mathrm{SF}}{\mathrm{D}^{\mathrm{T}}}\right) \frac{\mathrm{D}^{\mathrm{T}}}{\mathrm{E}^{\mathrm{T}}}\right] ; \\
& \text { Roe }=\left[\operatorname{Roa}+(\text { Roa }- \text { Rod }) \frac{\mathrm{D}^{\mathrm{T}}}{\mathrm{E}^{\mathrm{T}}}\right]
\end{aligned}
$$

If we consider that the company pays taxes on the basis of a single rate of tax $\left(\mathrm{T}_{\mathrm{m}}\right)$ and that the effect of extraordinary items (SX) can be calculated on a flat rate $\left(\mathrm{S}_{\mathrm{m}}\right)$, we can express this as follows:

$$
\text { Roe }=\left[\text { Roa }+(\text { Roa }- \text { Rod }) \frac{D^{T}}{E^{T}}\right]\left(1-T_{m}\right)\left(1-S_{m}\right)
$$

Equation 13 allows decomposing the return on capital to be used to analyze the performance of cooperative enterprises and to compare the reclassified and nonreclassified annual accounts and it also allows the calculation of the Altman EM Score, however, that the EM-Score follows an accounting approach and it could be possible to have differences between economic performance and financial results, particularly when the processing cycle is long lasting and the company requires a high capital intensity (Iotti and Bonazzi, 2012).

\subsection{The Research Plan}

The analysis was conducted on a sample of 100 cooperative firms operating in countries in the Mediterranean Basin; cooperatives are located in Northern Italy (Lombardia, Emilia-Romagna and Veneto regions). The data were randomly drawn from the annual accounts in the "Analisi informatizzata delle aziende italiane" AIDA database considering base year 2008; the date extraction covers the fiveyear period from 2008 to 2012 and uses the annual accounts filed by cooperatives each year at the Registrar of Companies. In the sample, 52 cooperatives work in the processing of fruit and vegetables, 41 cooperatives work in the milk processing industry and 7 are fishing cooperatives. We consider a total of 469-year firm observations because 31 observations were not used in calculations as they were missing in the database. The data analysis was performed using the SPSS statistical package, issue 19. The random extraction from the database of the 100 firms in the sample takes into account these extraction parameters: (1) The extracted firms are cooperative firms as defined in the civil code and in the sample, limited company firms are not included; (2) the extracted firms are classified as agrofood firms in accordance with the classification of 
the National Institute of Statistics of each country; (3) the turnover of the extracted firms is between 2 and 50 million euros, in compliance with the definition of SMEs. This article develops the analysis as follows: (a) We calculate the average annual account data (income statement and balance sheet) of the sample firms; (b) we reclassify the annual account of the cooperative, calculating the averages of the income statement and the balance sheet in the reclassified form; (c) we calculate financial ratios according to the DuPont approach for reclassified and nonreclassified annual accounts; (d) we calculate the Altman EMScore; (e) we test whether there are statistically significant differences in the value of financial ratios for reclassified and nonreclassified annual accounts; (f) we examine whether there are statistically significant differences in the value of the EM-Score for reclassified and nonreclassified annual accounts.

\section{RESULTS}

\subsection{Analysis of Annual Account}

The descriptive analysis considers the annual account of the cooperative in the reclassified and nonreclassified form. The reclassification allows highlighting, as shown in the methodological part of this article, to more correctly express the typicality of the cooperative's management. In Table $\mathbf{1}$, the average data for the balance sheet of the sample firms are considered. The data show that cooperatives have a high investment in Working Capital (WC ${ }^{\mathrm{a}}$ is $62.12 \%$ of TA), whereas $\mathrm{E}^{\mathrm{T}}$ has a low value-that is, $10.87 \%$ of TS. The balance sheet of the cooperative (not reclassified) provides an evidence for undercapitalization, so that $\mathrm{D}^{\mathrm{f}}$ is $37.62 \%$ of TS and the shareholder loans are $15.86 \%$ of TS. The reclassified balance sheet (Table 1) has quite different values. In fact, $\mathrm{E}^{\mathrm{T}}$ has a value equal to $29.70 \%$ of TS and debts are $70.30 \%$, which are at a lower value compared with the value of $89.13 \%$ of the nonreclassified balance sheet.

Even the income statement shows interesting data (as in Table 2). In fact, there is a considerable difference between the reclassified and the nonreclassified income statement. The agricultural raw material cost is $46.61 \%$ of the value of production in the reclassified income statement, whereas it is $36.16 \%$ in the reclassified form. SF is also different in the reclassified form, which accounts for $4.36 \%$ of VP compared with $5.06 \%$ of the nonreclassified income statement. The profit of the income statement is $3.89 \%$ of VP (nonreclassified income statement), while $15.04 \%$ of VP (reclassified income statement).

The analysis of financial ratios is carried out (Table 3) considering Return on Equity (ROE), Return on Asset (ROA), Return on Debts (ROD) and Debt to Equity Ratio (DER); these ratios express the performance of equity capital (ROE), return on capital employed (ROA), the Cost of Debt (ROD) and the debt level (DER). The analysis (Table 3) shows that the return on capital (ROE and ROA) is higher in the reclassified income statement, whereas the cost of debt (ROD) and the Debt level (DER) are lower in the reclassified data. With regard to access to credit, the EM-Score is greater for the reclassified data, both for the average value and for the median value. This is caused by the values of $\alpha_{2} X_{2}, \alpha_{3} X_{3}$ and $\alpha_{4} X_{4}$, which are higher in the reclassified data.

Table 1. Balance sheet of the cooperatives in the sample-2008/2012 data

\begin{tabular}{|c|c|c|c|c|}
\hline Values & $\begin{array}{l}\text { Cooperative balance } \\
\text { Sheet average }(€)\end{array}$ & $\begin{array}{l}\text { Cooperative balance } \\
(\%) \text { (TA) }\end{array}$ & $\begin{array}{l}\text { Cooperative balance } \\
\text { sheet redassified average }(€)\end{array}$ & $\begin{array}{l}\text { Cooperative balance } \\
\text { redassufied } \%(\mathrm{TA})\end{array}$ \\
\hline FA & $6,051,676$ & 36.50 & $6,051,676$ & 35.01 \\
\hline $\mathrm{WC}^{\mathrm{a}}$ & $10,299,852$ & 62.12 & $10,299,852$ & 59.59 \\
\hline $\mathrm{L}$ & 230,233 & 1.39 & 931,782 & 5.39 \\
\hline TA & $16,581,761$ & 100.00 & $17,283,309$ & 100.00 \\
\hline $\mathrm{E}^{\mathrm{sc}}$ & $1,032,340$ & 6.23 & $1,032,340$ & 5.97 \\
\hline$E^{r}$ & 525,642 & 3.17 & 525,642 & 3.04 \\
\hline$E^{\mathrm{ds}}$ & 0 & 0.00 & $2,629,257$ & 15.21 \\
\hline$\prod^{\mathrm{PT}}$ & 244,943 & 1.48 & 946,490 & 5.48 \\
\hline $\mathrm{E}^{\mathrm{T}}$ & $1,802,924$ & 10.87 & $5,133,730$ & 29.70 \\
\hline$D^{f}$ & $6,237,495$ & 37.62 & $6,237,495$ & $36,09.00$ \\
\hline $\mathrm{D}^{\mathrm{s}}$ & $2,629,257$ & 15.86 & 0 & 0.00 \\
\hline $\mathrm{WC}^{1}$ & $5,912,084$ & 35.65 & $5,912,084$ & 34.21 \\
\hline $\mathrm{D}^{\mathrm{T}}$ & $14,778,836$ & 89.13 & $12,149,579$ & 70.30 \\
\hline TS & $16,581,761$ & 100.00 & $17.283,309$ & 100.00 \\
\hline
\end{tabular}

Source: Our processing of directly collected data 
Table 2. Income statement of the cooperatives in the sample-2008/2012

\begin{tabular}{llcll}
\hline Values & $\begin{array}{l}\text { Cooperative balance } \\
\text { sheet average }(€)\end{array}$ & $\begin{array}{l}\text { Cooperative balance } \\
(\%)(\mathrm{TA})\end{array}$ & $\begin{array}{l}\text { Cooperative balance } \\
\text { sheet redassified average }(€)\end{array}$ & $\begin{array}{l}\text { Cooperative balance } \\
\text { redassufied } \%(\text { TA) }\end{array}$ \\
\hline VP & $6,294,137$ & 100.00 & $6,294,137$ & 100.00 \\
R & $-2,933,391$ & -46.61 & $-2,275,888$ & -36.16 \\
S & $-934,904$ & -14.85 & $-934,904$ & -14.85 \\
L & $-1,339,666$ & -21.28 & $-1,339,666$ & -21.28 \\
O & $-112,943$ & -1.79 & -112.943 & -1.79 \\
EBITDA & 973,233 & $15,46.00$ & $1,630,735$ & 25.91 \\
D & $-62,774$ & -1.00 & $-62,774$ & -1.00 \\
A & $-251,102$ & -3.99 & $-251,102$ & -3.99 \\
EBIT & 659,356 & 10.48 & $1,316,859$ & 20.92 \\
SF & $-318,671$ & -5.06 & $-274,626\left(\mathrm{SF}^{\mathrm{coop}}\right)$ & -4.36 \\
SX & 1,825 & 0.03 & 1,825 & 0.03 \\
$\prod^{\mathrm{aT}}$ & 342,510 & 5.44 & $1,044,058\left(\Pi^{\mathrm{aTcoop}}\right)$ & 16.59 \\
T & $-97,567$ & -1.55 & -97567 & -1.55 \\
$\prod^{\mathrm{p}^{\mathrm{T}}}$ & 244,943 & 3.89 & $946,490\left(\Pi^{\mathrm{pToop}}\right)$ & 15.04 \\
\hline
\end{tabular}

Source: Our processing of directly collected data

Table 3. Ratios and EM-Score values of the cooperative in the sample-2008/2012

\begin{tabular}{lllll}
\hline & $\begin{array}{l}\text { Mean values } \\
\text { Not redclassified } \\
\text { Values }\end{array}$ & $\begin{array}{l}\text { Median values } \\
\text { Not redclassified } \\
\text { annual account }\end{array}$ & $\begin{array}{l}\text { Mean values } \\
\text { redclassified } \\
\text { annual account }\end{array}$ & $\begin{array}{l}\text { Median values } \\
\text { redclassified } \\
\text { annual account }\end{array}$ \\
\hline ROE & 0.22590 & 0.1376 & 0.2817 & 0.2237 \\
ROA & 0.04350 & 0.0379 & 0.0865 & 0.0795 \\
ROD & 0.02350 & 0.0213 & 0.0261 & 0.0218 \\
DER & 13,5389 & 9,2623 & 3,7773 & 2,8792 \\
$\alpha_{1} X_{1}$ & 1.79610 & 1.7786 & 1.7149 & 1.6746 \\
$\alpha_{2} \mathrm{X}_{2}$ & 0.10840 & 0.1069 & 0.6122 & 0.5972 \\
$\alpha_{3} \mathrm{X}_{3}$ & 0.28330 & 0.2516 & 0.5379 & 0.5046 \\
$\alpha_{4} \mathrm{X}_{4}$ & 0.13920 & 0.1305 & 0.5151 & 0.4448 \\
EM-score & 5.57690 & 5.5516 & 6.6301 & 6.6801 \\
\hline Soure & & &
\end{tabular}

Source: Our processing of directly collected data

Table 4. Comparison of ratios and EM-Score values-paired samples (t-Student)

\begin{tabular}{lllll}
\hline Comples of value & Mean S. Error & $\mathrm{t}$ & DF & Sig. (2-tailed) \\
\hline Couple 1 ROE-ROE_Adj & 0.0184841 & -2.886 & 469 & $0.004^{* *}$ \\
Couple 2 ROA-ROA_Adj & 0.0012661 & -33.154 & 469 & $0.000^{* *}$ \\
Couple 3 ROD-ROD_Adj & 0.0004189 & -6.295 & 469 & $0.000^{* *}$ \\
Couple 4 SER-SER_Adj & 0.6880703 & 14.187 & 469 & $0.000^{* *}$ \\
Couple $5 \alpha_{1} X_{1}-\alpha_{1} X_{1}+A d j$ & 0.0008357 & 14.839 & 469 & $0.000^{* *}$ \\
Couple $6 \alpha_{2} X_{2}-\alpha_{2} X_{2}+$ Adj & 0.0042158 & -36.607 & 469 & $0.000^{* *}$ \\
Couple $7 \alpha_{3} X_{3}-\alpha_{3} X_{3}+$ Adj & 0.0010531 & -35.999 & 469 & $0.000^{* *}$ \\
Couple $8 \alpha_{4} X_{4}-\alpha_{4} X_{4}+A d j$ & 0.0126142 & -28.374 & 469 & $0.000^{* *}$ \\
Couple 9 EM-score-EM-Score_Adj & 0.0265180 & -40.283 & 469 & $0.000^{* *}$ \\
\hline
\end{tabular}

**. Value significant at the 0.01 level (2-tailed); *.Value significant at the 0.05 level (2-tailed); Source: Our processing of directly collected data

\subsection{Statistical Analysis of the Comparison of Ratios and EM-Score Values}

The Kolmogorov-Smirnov statistic D (KSD) shows that all the values follow the normal distribution. Applying KSD, we accept the null hypothesis $(0.001$ significance level) for all values of normal distribution ratios and EM-Score values. We then consider a parametric approach of analysis in order to compare the average values of ratios and EM-Scores (Table 4), applying a Student $t$ statistic for paired samples. The analysis conducted in Table $\mathbf{4}$ allows us to quantify if the 
values of the parameters have statistically significant differences. The analysis is conducted considering two types of comparisons. The couples of values from 1 to 4 consider ratios calculated with the DuPont approach; the aim of the analysis was to calculate if the ratios are different when the calculation considers reclassified or nonreclassified data. The comparison of the couples of values from 5 to 9 aimed to quantify the firms' capacity to access to credit, calculated considering the Altman EM-Score index; the analysis is conducted considering reclassified and nonreclassified data. All the comparisons are made applying a parametric approach, such as the Student $t$ statistic for paired samples.

\section{DISCUSSION}

Cooperative enterprises play a vital role in agricultural development, particularly in developing countries, because cooperatives allow the problem of lack of capital in agriculture and rural families to be overcome. At the same time, cooperatives allow all the profits of agricultural activity to be kept at the local level, which can then be used to activate local chains of multiplication of income. Moreover, cooperatives play an important role in the agri-food system. In northern Italy, cooperative enterprises are particularly numerous in the transformation of milk into cheese (ParmigianoReggiano and Grana Padano PDO) and in the sector of canned vegetables (fruit and tomato products in particular). Even in food distribution cooperatives play a central role at a national level, with some of the major players in the distribution of Italian food active in cooperative form. The correct analysis of the annual account of the cooperatives is therefore of great importance to properly analyze the efficiency and the financial strength of a large number of agri-food firms. Indeed, if the cooperatives were not examined correctly by Banks, these firms could be disadvantaged, with the destination of capital to other sectors, as several researchers have shown (Lerman and Parliament, 1993; Briggeman et al., 2009). However, cooperative enterprises have difficulties in credit access and this is also determined by the typicality of the cooperative annual account that does not allow the real management results to be adequately highlighted. The annual account of the cooperative tends to underestimate the profit generated by the management and the equity conferred by members. In this article, the analysis has shown significant results about this topic. The reclassification of the budget that is proposed makes it possible for the profit of the cooperative to be correctly highlighted, taking into account values higher than the market prices; this is the price that agricultural raw materials conferred by members obtain from the cooperative. In this way, it is also possible to calculate the profit for members to participate in the cooperative. The reclassification proposal also considers the capital contributions made by shareholders in the form of loans by classifying these values as equity. The analysis allows some reflections and future research developments. First, the profit for the cooperative members that emerges from the reclassified income statement is statistically higher compared with the nonreclassified data. This is due in large part to higher prices that members of cooperatives in the sample obtain by giving the agricultural raw material for processing to the cooperative; the agricultural commodities are paid at a price higher than what they would receive on the market. In addition, if we take into account the cost of sales and transaction costs caused by a direct sale on the market, this result would even be more positive. We can also consider that some farmers would not even be able to sell their products on the market, for example, because the quantity of production is too small. The analysis shows that there is a benefit for members of the cooperative firms and this advantage is relevant and statistically significant. In fact, the profit that emerges from the reclassified annual account of cooperative firms is equal to $15.04 \%$ of the production value, whereas it is only equal to $3.89 \%$ in the nonreclassified cooperative data. Similarly, the ROE_Adj median is $22.37 \%$, whereas the median ROE is $13.76 \%$. The usual analysis of the budget does not include reclassifications and tends to underestimate the real benefit of the cooperative and this is also demonstrated in the statistical comparison between profitability ratios, where both ROE_Adj and ROA_Adj were higher than ROE and ROA calculated without the cooperative's balance sheet reclassification suggested in this article. The evidence the profitability of the cooperatives, due to a more accurate measurement, makes attractive to invest in risk and debt capital, then channeling in the cooperative sector investments that would otherwise have been allocated to other types of firms. At the same time, the level of debt that emerges from the balance sheet is incorrectly analyzed applying traditional ratios. In fact, if we consider the loans from shareholders as part of the equity, as suggested in this article, we see that DER_Adj is significantly lower than DER calculated using the traditional approach without reclassification of the balance sheet. In the comparison of DER_Adj (2.8792) and DER (9.2623), the difference in value is highly significant. Cooperative enterprises in 
the sample are therefore much less indebted than they appear in reality from the annual balance sheet data and then the reclassification of the balance sheet appears important to correctly understand the level of corporate debt. With regard to credit access, with the application of Altman EM-Score, this article highlights important results. In fact, all four values of the parameters of EMScore are statistically higher in the case of the reclassified financial data. Cooperative enterprises have EM-Score investment grade values of 5.5759 (average value) and 5.5516 (median value). These values, however, are higher in the case of the reclassified balance sheet, with an average value of 6.6301 and a median value of 6.6801 . This difference is statistically significant at the 0.01 level (two-tailed test) and it is therefore possible to note that the reclassified cooperative budget allows a value of EM-Score to be more correctly obtained and this is higher than the EMScore calculated on nonreclassified data. Cooperative enterprises in credit access may have an underestimation of financial strength and therefore may not receive credit because of banks' incorrect consideration of several annual data. In fact, banks do not take into account reclassification, which could correctly express the balance typicality of cooperatives. If reclassification was considered, the balance sheet values of cooperatives not only would be considered in a more correct way but also would have an easier access to credit.

\section{CONCLUSION}

The analysis in this article, applied to a sample of agricultural cooperative firms operating in the Mediterranean Basin, shows that cooperative firms suffer from the traditional form of annual accounting because this does not correctly show the profit and the level of corporate debt. In this article, we suggest some adjustments to the annual account and these adjustments allow the calculation of the reclassified annual account for the cooperative firms. This reclassification allows a more accurate representation of the cooperative's profit and debt/equity values conferred by the cooperative members. To achieve this goal, in this article, we applied ratios according to the traditional DuPont scheme to the annual account of the cooperative in the considered sample. The analysis shows that the ratios of profitability (ROE, ROA), cost of debt (ROD) and debt level (DER) are statistically different when calculated for reclassified and nonreclassified annual accounts. In particular, cooperative firms would be characterized by higher earnings and lower debt if the analysis is carried out, as suggested in this article, using the reclassified annual account. In addition, an index traditionally used by banks to assess the credit risk (Altman EM-Score) appears statistically different when calculated on the reclassified annual accounts with respect to the nonreclassified annual accounts. In particular, the value of the EM-Score is higher on the reclassified data and this shows that the traditional nonreclassified annual account approach penalizes cooperatives and also leads to a more difficult access to credit. We can therefore note that the suggested reclassifications can help cooperatives to be analyzed by banks in a truer and more correct way, thereby reducing the difficulty of access to credit. The results of the analysis show that the adjustments to the budget of cooperatives suggested in this article allow a more correct expression of the results of the operations and the financial position of the agricultural cooperative. The result, analyzed in terms of scoring, is significantly better than the result obtained with a traditional analysis. Moreover, other reclassifications could be defined and applied for the annual account analysis of the cooperative of workers and further research developments on this theme are possible. The research, however, has limitations; in fact, the analysis was conducted on a relatively small sample of firms, so it would be appropriate to expand the research to other countries, even considering a greater number of firms. In addition, the corrections that are suggested in the research need to be considered in the annual account data. This change can only be made by Law; for application of the research is then necessary to amend the Law on the annual account, or alternatively, the information required have to be provided by companies on a voluntary basis. This places a limitation on the practical application of the results of that research. In the future, new research may provide a comparative analysis of the legislation on the annual account of cooperatives in different countries, in order to verify whether the financial report are different and also check if the annual account of the cooperatives has different rules. In this way it might be possible to verify if the laws of different countries take into account the typicality of cooperatives annual account.

\section{ACKNOWLEDGEMENT}

This study is a result of the full collaboration of all the authors. However G. Bonazzi wrote paragraphs Introduction, Discussion and Conclusion while M. Iotti wrote paragraphs Material and Methods, Results. The authors thank analisiaziendale. It for IT assistance, particularly for the EM-Score database. 


\section{RERERENCES}

Al-Ajmi, J., 2008. The usefulness of corporate governance and financial ratios to credit and financial analysts: Evidence from bahrain. Eur. J. Econom., 11: 41-63.

Albaek, S. and C. Schultz, 1998. On the relative advantage of cooperatives. Economic Lett., 59: 397-401. DOI: 10.1016/S0165-1765(98)00068-8

Alrafadi, K.M.S. and M. Md-Yusuf, 2011. Comparison between financial ratios analysis and balanced scorecard. Am. J. Econ. Bus. Admin., 3: 618-622.

Al-Razeen, A. and E. Karbhari, 2004. Annual corporate information: Importance and use in Saudi Arabia. Mangerial Audit. J., 19: 201-219. DOI: 10.1108/02686900410509910

Altman, E.I. and M. Ong, 2002. Credit Ratings: Methodologies, Rationale and Default Risk. 1st Edn., Risk Waters Group, London, ISBN-10: 1899332693 , pp: 534.

Altman, E.I., 1968. Financial ratios, discriminant analysis and the prediction of corporate bankruptcy. J. Finance, 23: 589-609. DOI: $10.1111 / \mathrm{j} .1540-$ 6261.1968.tb00843.x

Altman, E.I., 1993. Corporate Financial Distress and Bankruptcy: A Complete Guide to Predicting and Avoiding Distress and Profiting from Bankruptcy. 1st Edn., Wiley and Sons, ISBN-10: 0471552534, pp: 356.

Altman, E.I., J. Hartzell and M. Peck, 1998. Emerging market corporate bonds-a scoring system. Emerg. Market Capital Flows, 2: 391-400. DOI: 10.1007/9781-4615-6197-2_25

Ashbaugh-Skaife, H., D.W. Collins and R. LaFond, 2006. The effects of corporate governance on firms' credit ratings. J. Account. Econom., 42: 203-243. DOI: 10.1016/j.jacceco.2006.02.003

Bahiraie, A., N.A. bt Ibrahim and A.K.M. Azhar, 2009. On the Predictability of Risk Box Approach by Genetic Programming Method for Bankruptcy Prediction. Am. J. Applied Sci., 6: 1748-1757. DOI: 10.3844/ajassp.2009.1748.1757

Beaver, W.H., 1966. Financial ratios as predictors of failure: Empirical research in accounting selected studies. J. Account. Res.

Blumenthal, R.G., 1998. This the gift to be simple: DuPont's framework for financial analysis. CFO Magazine Senior Financial Executives, 1: 32-38.

Bonazzi, G., M. Iotti and D. Sfulcini, 2009. Typical product of quality and cooperation: ParmigianoReggiano PDO cheese, production, trade and cooperative management indexes, 315-338, in the role of cooperatives in the European agri-food system. Bononia University Press, Bologna.
Bonazzi, G., M. Iotti and F. Paduano, 2012. Valutazioni di convenienza e di sostenibilità per le imprese del comparto del Prosciutto di Parma Dop: Un'analisi attraverso l'applicazione di indici economici e finanziari. Rivista di Economia Agraria, 67: 61-98.

Briggeman, B.C., Towe C.A. and M.J. Morehart, 2009. Credit constraints: Their existence, determinants and implications for U.S. farm and nonfarm sole proprietorships. Am. J. Ag. Econom., 91: 275-289. DOI: $10.1111 / \mathrm{j} .1467-8276.2008 .01173 . \mathrm{x}$

Chaddad, F., M. Cook and T. Heckelei, 2005. Testing for the presence of financing constraints in US agricultural cooperatives: An investment behavior approach. J. Agric. Econom., 56: 385-397. DOI: 10.1111/j.1477-9552.2005.00027.x

Cook, M. and F.R. Chaddad, 2004. Redesigning cooperative boundaries: The emergence of new models. Am. J. Agric. Econom., 86: 1249-1253. DOI: $10.1111 /$ j.0002-9092.2004.00673.x

Cook, M., 1995. The future of U.S. Agricultural cooperatives: A neo-institutional approach. Am. J. Agric. Econom., 77: 1153-1159. DOI: $10.2307 / 1243338$

Cotteril, R.W., 1987. Agricultural cooperatives: A unified theory of pricing, Finance and Investment. ACS Service Report, Washington DC, pp: 171-258.

Ellinger, P., 2009. Financial markets and agricultural credit at a time of uncertainty. Choices, 24: 32-35.

Fama, E. and K. French, 1996. Multifactor explanations of asset pricing anomalies. J. Finance, 51: 55-84. DOI: 10.1111/j.1540-6261.1996.tb05202.x

Fama, E. and K. French, 1998. Value versus growth: The international evidence. J. Finance, 53: 1975-1999. DOI: $10.1111 / 0022-1082.00080$

Firer, C., 1999. Driving financial performance through the du pont identity: A strategic use of financial analysis and planning. Financial Practice Educ., 9: 34-46.

Fulton, M.E., J.R. Fulton, J.S. Clark and C. Parliament, 1995. Cooperative growth: Is it constrained?, Agribusiness: Int. J., 11: 245-261. DOI: 10.1002/1520-6297(199505/06)11:3<245::AIDAGR2720110306>3.0.CO;2-J

Hendriske, G.W.J. and C.P. Veerman, 2001. Marketing cooperatives and financial structure: A transaction costs economics analysis. Agric. Econom., 26: 206-216. DOI: 10.1111/j.15740862.2001.tb00064.X

Hendriske, G.W.J. and J. Bijman, 2002. Ownership structure in agrifood chains: The marketing cooperative. Am. J. Agric. Econom., 84: 104-119. 
Iotti, M. and G. Bonazzi, 2012. EBITDA/EBIT and Cash flow based ICRs: A comparative approach in the agro-food system in Italy. Financial Asset Invest., 2: 19-31.

Lerman, Z. and C. Parliament, 1993. Financing growth in agricultural cooperatives. Rev. Agric. Econom., 15: 431-441. DOI: 10.2307/1349479

LeVay, C., 1983. Agricultural co-operative theory: A review. J. Agric. Econom., 34: 1-44. DOI: 10.1111/j.1477-9552.1983.tb00973.x

Limsombunchai, V., C. Gan and M. Lee, 2005. An analysis of credit scoring for agricultural loans in thailand. Am. J. Applied Sci., 2: 1198-1205. DOI: 10.3844/ajassp.2005.1198.1205.

Little, P.L., J.W. Mortimer, M.A. Keene and L.R. Henderson, 2009. Evaluating the effect of recession on retail firms' strategy using DuPont method: 2006-2009. J. Finance Accountancy.

Mishra, A., C. Wilson and R. Williams, 2009. Factors affecting financial performance of new and beginning farmers. Agric. Finance Rev., 69: 160179. DOI: $10.1108 / 00021460910978661$

Moss, C.B., A.K. Mishra and D. Cheikhna, 2009. Decomposing agricultural profitability using dupont expansion and theil's information approach, Louisiana State University, Wisconsin.

Nguyen, G.H., 2005. Using neutral network in predicting corporate failure. J. Soc. Sci., 1: 199-202. DOI: 10.3844/jssp.2005.199.202

Nissim, D. and S. Penman, 2001. Ratio analysis and equity valuation: From research to practice. Rev. Account. Stud., 6: 109-154. DOI: 10.1023/A:1011338221623
Pearce, J.A., 2007. The value of corporate financial measures in monitoring downturn and managing turnaround: An exploratory study. J. Managerial, 15: 253-270.

Rathbone, R.C., 1995. Understanding cooperatives: Financing cooperatives. Department of Agriculture. United States.

Rogers, R.T. and B.W. Marion, 1990. Food manufacturing activities of the largest agricultural cooperatives: Market power and strategic behavior implications. J. Agric. Cooperat., 5: 59-73.

Ross, S.A., Westerfield, R. and D. Bradford, 1999. Fundamentals of Corporate Finance: Standard Edition. McGraw-Hill Education, New York.

Sexton, R.J., 1990. Imperfect competition in agricultural markets and the role of cooperatives: A spatial analysis. Am. J. Agric. Econom., 72: 709-720. DOI: $10.2307 / 1243041$

Theodoropoulou, H., R. Mitoula, O. Astara and P. Kaldi, 2008. Applied issues of agritourism cooperation and sustainable endogenous development. Am. J. $\begin{array}{llll}\text { Applied } & \text { Sci., } & \text { 5: } & \text { 1588-1594 }\end{array}$ DOI: 10.3844/ajassp.2008.1588.1594

Tianwei, Z. and P.N. Ellinger, 2006. Credit risk and financial performance assessment of illinois farmers: A comparison of approaches with farm accounting data. Proceedings of the American Agricultural Economics Association Annual Meeting, Jul. 23-26, Long Beach, California, pp: 1-28.

Tirole, J. and P. Rey, 2001. Financing and access in cooperatives. Working Paper, L'Institut d'economie industrielle. University of Toulouse, Toulouse France. 